\title{
Assessment of Health Care Waste Generation Rate and Evaluation of its Management System in Mizan Tepi University Teaching Hospital (MTUTH), Bench Maji Zone, South West Ethiopia
}

\author{
Asrat Meleko* and Abebe Adane \\ Department of Public Health, Mizan -Tepi University, Ethiopia
}

Submission: January 15, 2018; Published: February 23, 2018

"Corresponding author: Asrat Meleko, Department of Public Health, Collage of Medicine and Health Sciences, Mizan-Tepi University, Ethiopia, Tel: +251-941-9897-97; Email: melekoasrat@gmail.com

\begin{abstract}
Background: Hospitals are established with the foremost rationale of protecting the community from any ailment. But during executing patient care activities, they create wastes which have the potential to cause harm to human beings and environment due to their unique characteristics.

Objective: To assess health care waste generation rate and evaluate its management system in Mizan Tepi University Teaching Hospital, South West Ethiopia

Method and Material: Facility based cross- sectional study was conducted in Mizan Tepi University teaching hospital from July 2015 to September 2016. Observational checklist was used to evaluate waste management system and weighting scale was used to quantify the generation rate of healthcare waste. Data was entered and analyzed using Epi Data V 3.1 and SPPSS version 20. Descriptive statistics were used to describe the health care waste generation rate. Kruskal Wallis test were used to test if there was significance difference between different departments with regard to total health care waste generation rate and types of waste. To assure the data quality calibration of weighting scales was made every morning. Data collectors were trained to use protective devises while collecting and measuring healthcare wastes.
\end{abstract}

Result and Discussion: The mean generation rate of health care waste in this hospital was $0.164 \mathrm{~kg} / \mathrm{bed} / \mathrm{day}$, of which $0.091 \mathrm{~kg} / \mathrm{bed} / \mathrm{day}$ (55.5\%) was general waste and the remaining $0.073 \mathrm{~kg} / \mathrm{bed} /$ day $(44.5 \%)$ was hazardous waste. There was statistically a significant difference to mean of total health care waste $(\chi 2=44.604$, p value $=0.001)$, general waste $(\chi 2=41.815$, $p$-value $=0.001)$ and hazardous waste generated $(\chi 2=44.324$, $p$-value $=0.000)$ between different wards. Waste segregation was not practiced at source of generation.

Conclusion and Recommendation: It is known that waste segregation at source of generation is crucial to improve waste management practices as well to decrease its volume. However, in this study area onsite segregation was not practiced appropriately. Also status of health care waste management practice with regard to storage, collection, treatment and disposal were not coherent with the WHO guideline. Therefore, the hospital management should enforce all groups for the proper application of the principle of waste management in a way safe to environment and public.

Keywords: Health Care Waste; Waste Segregation; Waste Generation; Hospital

\section{Introduction}

Recently the magnitude of waste is increasing due to a number of factors such population increase, industrialization, urbanization and others. This situation has direct effect to the environment if there is inappropriate system used during collection, transportation, treatment and disposal of waste. Out of the total flow of waste generated, the most dangerous types are hazardous waste. Because, unlike other types of wastes they have unique properties such as they are explosive, flammable, toxic, carcinogenic, corrosive, or infectious. The considerable fraction of those hazardous wastes is generated from different health care facilities mainly from hospitals [1].
Hospitals are established with the main purpose of protecting the community from any disease. But during executing patient care activities, they produce certain waste which has the potential to cause harm to human beings and environment due to their unique properties. Generally, the different types of medical wastes generated from hospitals are broadly grouped in two categories by World Health Organization (WHO). This medical waste is classified as non-risk or general healthcare waste, which is comparable to domestic waste and as hazardous waste, which has the potential to pose a variety of health risks [2]. 
Of those types of hospitals wastes more attention were given for hazardous wastes due to its severe impact. According to a WHO report, around $85 \%$ of the hospital wastes are actually non hazardous which comes mostly from the administrative and housekeeping functions of health-care establishments and may also include waste generated during maintenance of healthcare premises, but the remaining $10-25 \%$ of hospital waste is regarded as hazardous and may create a variety of health risks which consists of infectious, pathological, chemical, sharps and radioactive material [3].

The quantity of health care waste generated will vary depending on different factors such as the hospital policies and practices and the type of care being provided. For instance, the data available from developed countries indicate a range from 1-5 Kg/bed/day, with substantial inter country and inter specialty differences while it is revealed in rural Hospitals of Africa that the total generation rate of medical waste estimated to be between $0.3-1.5 \mathrm{~kg} / \mathrm{bed} /$ day (5-20\% Hazardous waste) [4].

Regardless of its adverse impact on the environment, health care workers, patients and in general the public, the World Health Organization (WHO) recognized that proper handling and management of medical waste is substantially undermined in many countries including developed countries [5]. A study conducted in district hospitals of Tumpat, Batu Pahat and Taiping (Malaysia) revealed that a continuous proper management of clinical waste in the hospitals was not practiced [6].

The problem with regard to medical waste is severe in developing countries. For instance, according to an assessment conducted in 22 developing countries by world health organization (WHO), it was identified that the proportion of healthcare facilities that do not use proper waste disposal methods ranges from $18 \%$ to $64 \%$ [7].

A study conducted in Sudan identified that the health care waste management practices observed in Khartoum state hospitals were not fully safe and have harmful environmental effects, which was characterized by absence of continuous segregation, collection, transportation and final disposal methods of pathological and other medical wastes [8].

In Ethiopia, like other African countries health care wastes in different hospitals are managed improperly. A study conducted in Debre Birhan zonal hospital identified that healthcare wastes were stored, collected, transported and disposed in a manner that creates health problems to the health worker, waste handler and the community [9].

Many studies confirmed that the effect of improper management of medical waste is responsible for large burden of associated injuries and diseases on the public in many countries. The unsafe disposal of medical waste, such as contaminated syringes and needles is caused 21 million hepatitis B virus (HBV) infections (32\% of all new infections; 2 million hepatitis $C$ virus (HCV) infections (40\% of all new infections; and at least 260,000 HIV infections (5\% of all new infections) [7].
In Ethiopia, the effects of healthcare wastes on people living surrounding the health facilities and on the environment are unknown. However some little studies done indicated that most people are at risk for hazardous (infectious and sharp) wastes which might be due to indiscriminate discharges of these wastes by the nearby health facilities [10].

Thus, poor management of health care waste in hospitals is a significant problem in most countries. It is imperative to improve existing waste management practice to prevent different groups of exposed community. Availability of adequate data with regard to waste generation and management practice of a given health care facility plays a great role in planning appropriate method. However, in Mizan Tepi university teaching hospital there was lack of data related with the aforementioned issue. Therefore, this research was aimed to fill the existing information gab by assessing the existing medical waste generation rate and management practices in MTU teaching hospital which may contribute for different groups to formulate evidence based design and plan of HCWM.

\section{Objectives}

\section{General Objective}

Assessment of solid health care waste generation rate and its management system in Mizan-Tepi University Teaching Hospital

\section{Specific Objectives}

a. To identify the type and nature of health care wastes generated in Mizan-Tepi University Teaching hospital, Bench Maji zone, South West Ethiopia

b. Estimate health care waste generation rate in MizanTepi University Teaching hospital Bench Maji zone, South West Ethiopia

c. To assess Health care waste management system in Mizan-Tepi University Teaching hospital Bench Maji zone, South West Ethiopia

\section{Methods and Materials}

\section{Study area and Period}

The study was conducted in different departments of Mizan Tepi university teaching hospital (MTUTH), located in Bench Maji zone, SWE, from July 2015 to September 2016. Mizan Tepi University teaching hospital is one of the pioneer hospitals in Bench Maji zone, with capital of Mizan Aman town, found in Aman sub town kebele 02 and landed on 9,7560m2. The capital of the zone is located at a distance of $574 \mathrm{~km}$ far from Addis Ababa, South West Ethiopia.

Types of services provided in this hospital include OPD, Inpatient treatment and care, Surgery, $\mathrm{MCH}$, Gynecology, Obstetrics, Laboratory and pharmacy. It has a total of 107 beds and 171 health professionals. Currently the hospital is serving many peoples who live in several zones of SNNPs and Gambella states with approximate catchment population of 2 million 
peoples.

\section{Study Design}

Facility based cross- sectional study was conducted to measure health care waste generation rate and describe current management practices in all departments of Mizan-Tepi University Teaching Hospital (MTUTH).

\section{Source Population}

Source population for this study was all three hospitals which are found in Bench Maji zone. From three hospitals Mizan Tepi University teaching hospital were selected randomly to assess health care waste generation rate and its management system. All departments which are found in this hospital are included in this study.

\section{Sampling Method}

There are a total of three hospitals in Bench Maji zone, including Mizan Tepi University Teaching Hospital (MTUTH). And we were selected this hospital purposefully. All departments in the hospital such as OPD, gynecology ward, medical ward, surgical ward, laboratory, pediatric ward, different offices and kitchen were included in this study by assuming them as major source for waste generated in the hospital.

\section{Data Collection Tools and Procedures}

Observational checklist was used to assess the current waste management system and weighting scale was used to quantify the generation rate of healthcare waste in all departments Mizan Tepi University Teaching Hospital (MTUTH). To estimate the amount of health care waste generated from each department collection and measurement were done daily for consecutive seven day from Monday to Sunday. Observational checklist was used to assess the management system in terms of segregation, collection, transportation, and treatment of health care wastes and how healthcare workers and waste handlers handled healthcare waste in all departments of the hospital.

To quantify the amount of health care waste generated plastic buckets and plastic bags of different colors that meet WHO norms was distributed according to the type of waste generated in different departments of the hospital. The buckets, safety box and plastic bags were labeled to indicate the different categories of health care waste, date of collection and sample number. Plastic bags were removed every morning and its weight is measured every day at a specified time using weighing scale.

\section{The Study Variables}

\section{Dependant Variables}

a) The amount of health care waste generated

b) Health care waste management practices

\section{Independent Variables}

a. Waste segregation practice b. Presence or absence of waste management policy

c. Materials used for waste storage, collection, and transportation

d. Number of bed

\section{Operational Definitions}

i. Health Care Waste/Medical Waste: Is defined as the total waste stream from a health care establishment, research facilities, laboratories, and emergency relief donations.

ii. General Waste: Domestic type of waste, packing material, wastewater from laundries etc.

iii. Infectious waste: Includes cultures and stocks of infectious agents from laboratories, waste from survey and autopsy on patients in isolation wards and dialysis from infected patients.

iv. Pathological Waste: Consists of tissues, organs, body parts, human fetuses, blood and body fluids.

v. Sharps: Includes items like needles, blades, broken glass etc. i.e. any item that can cause a cut or puncture.

vi. Pharmaceutical Wastes: Consists of pharmaceutical products, drug and chemicals those have been returned from the wards.

\section{Data Analysis}

Data was entered and analyzed using Epi Data 3.1 and SPPSS version 20. Descriptive statistics such as mean, variance and standard deviation were used to describe the health care waste generation rate. Kruskal Wallis test were used to test if there was significance difference between different departments with regard to total health care waste generation rate and types of waste. Finally the result was presented using tables and graphs. The annual waste generation rates were estimated by assuming the activities related with waste generation are uniform throughout the year and thus it was obtained by multiplying daily generation rate by 365 days of the year.

\section{Data Quality Assurance}

To assure the data quality training of data collectors and supervisors were given. During data collection time weighing scales was calibrated every morning using a known weight before the actual measurements start. Close and routine onsite observation was made by the investigator during the collection and measurement of wastes.

\section{Ethical Clearance}

Ethical clearance was obtained from Mizan Tepi University (MTU), via collage of health sciences. Permission for data collection was obtained from Mizan Tepi University Teaching Hospital. Data collectors were trained to use protective devises while collecting and measuring healthcare wastes. 


\section{Result}

\section{General Description of the Hospital and Types of Health Care Services Addressed in this Study}

Mizan Tepi university teaching hospital is one of the major hospitals visited by large number of patients in Bench Maji zone. During data collection time the hospital has a total of 107 beds. Monthly in average 1800 and 4200 inpatient and outpatients visit the hospital respectively. The major services given in this hospital which was expected to generate different types of medical wastes and included in this study were OPD, gynecology

Table 1: Total waste generated in different departments by type of waste within 7 days of data collection time in MTU teaching hospital, Bench Maji zone, SWE, 2017.

\begin{tabular}{|c|c|c|c|c|c|c|c|c|c|}
\hline Type of waste & $\begin{array}{l}\text { Gynecology } \\
\text { ward (kg) }\end{array}$ & $\begin{array}{c}\text { Medical } \\
\text { ward (kg) }\end{array}$ & $\begin{array}{c}\text { Surgical } \\
\text { ward (kg) }\end{array}$ & $\begin{array}{l}\text { OPD } \\
\text { ward } \\
(\mathrm{kg})\end{array}$ & $\begin{array}{c}\text { Labora } \\
\text { tory } \\
\text { (Kg) }\end{array}$ & $\begin{array}{l}\text { Pediatrics } \\
\text { kg/day }\end{array}$ & $\begin{array}{c}\text { Office } \\
\text { (Kg) }\end{array}$ & $\begin{array}{l}\text { Kitc } \\
\text { hen } \\
\text { (Kg) }\end{array}$ & $\begin{array}{c}\text { Total (by } \\
\text { type) }\end{array}$ \\
\hline Pathological Waste & 24.6 & - & - & - & - & - & - & - & 24.60 \\
\hline Infectious Waste & 2.37 & 1.73 & 3.31 & 3.12 & 2.54 & 2.07 & & - & 15.14 \\
\hline $\begin{array}{l}\text { Pharmaceutical } \\
\text { Waste }\end{array}$ & 1.61 & 1.82 & 2.59 & 1.17 & - & 1.01 & - & - & 8.20 \\
\hline Sharps Waste & 0.094 & 0.335 & 0.089 & 1.64 & 2.85 & 1.62 & - & - & 6.628 \\
\hline General Waste & 6.89 & 9.05 & 7.8 & 1.9 & 1.5 & 9.71 & 1.57 & 30 & 68.42 \\
\hline $\begin{array}{l}\text { Total Health Care } \\
\text { Waste (By Ward) }\end{array}$ & 35.564 & 12.935 & 13.789 & 7.83 & 6.89 & 14.41 & 1.57 & 30 & 122.99 \\
\hline $\begin{array}{l}\text { Mean Weight Per } \\
\text { Day }\end{array}$ & 5.08 & 1.85 & 1.97 & 1.12 & 0.98 & 2.06 & 0.22 & 4.29 & 17.57 \\
\hline
\end{tabular}

Medical waste generation rate by type of waste: Different types of wastes were generated in this studied hospital with varies magnitude. For instance from total hazardous wastes generated in MTU teaching hospital pathological waste ward, medical ward, surgical ward, laboratory, pediatric ward, different offices and kitchen.

\section{Waste Generation Rate In MTU Teaching Hospital}

Daily medical waste generation rate in different departments: The total mean generation rate of health care waste in MTU teaching hospital was $0.164 \mathrm{~kg} / \mathrm{bed} /$ day, of which $0.091 \mathrm{~kg} / \mathrm{bed} /$ day (55.5\%) was general waste and the remaining $0.073 \mathrm{~kg} / \mathrm{bed} /$ day (44.5\%) was hazardous waste (pathological, infectious, pharmaceutical and sharps)-(Table 1). constitute the largest portion of hazardous waste which were $0.033 \mathrm{~kg} / \mathrm{bed} /$ day and the lowest were sharp waste, $0.009 \mathrm{~kg} /$ bed/day (Table 2).

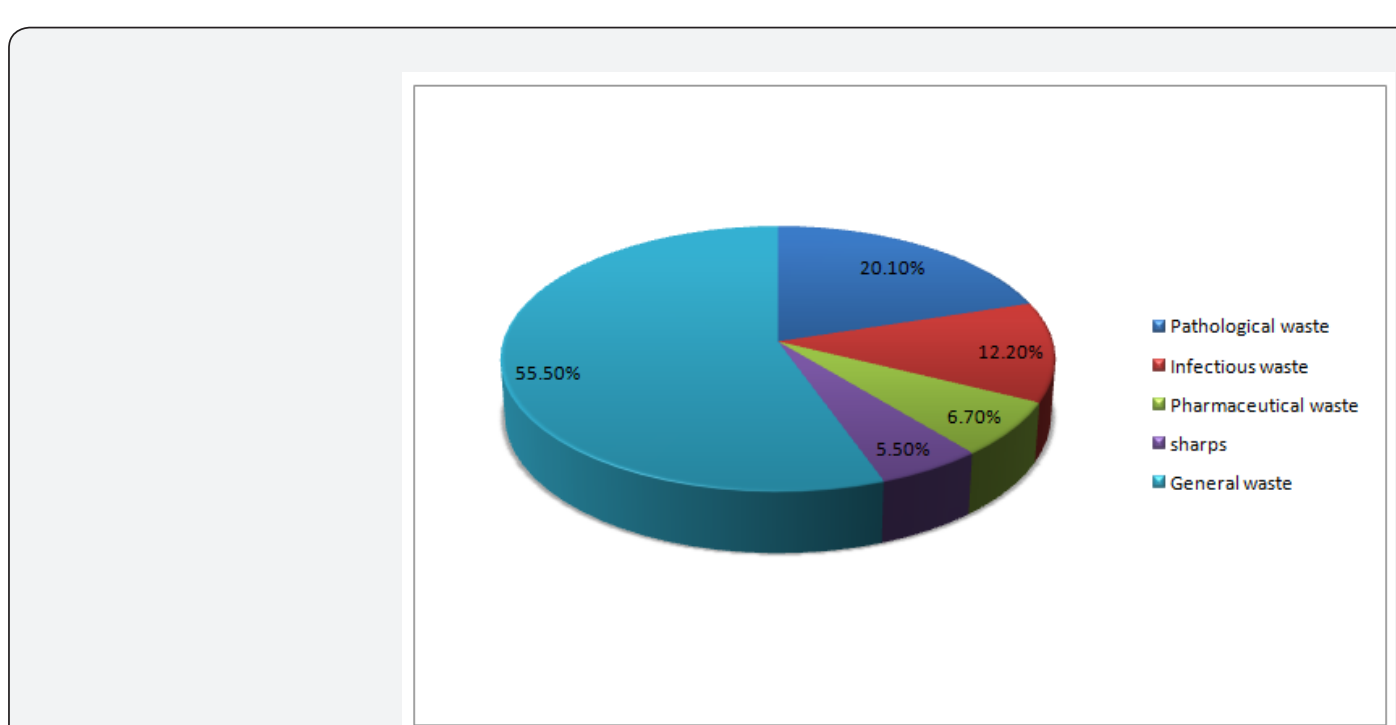

Figure 1: Total generation rate of different type of health care waste by type in seven days of data collection time (in Kg) in MTU teaching hospital, Bench Maji zone, SWE, 2017. 
Table 2: Average daily generation of health care waste by types of waste in MTU teaching hospital, Bench Maji zone, SWE, 2017.

\begin{tabular}{|c|c|c|}
\hline Type of Waste & $\begin{array}{c}\text { Mean (Average Daily Health } \\
\text { Care Waste Generated in All Wards) }\end{array}$ & Kg/Bed/Day \\
\hline Pathological Waste & 3.51 & 0.033 \\
\hline Infectious Waste & 2.16 & 0.020 \\
\hline Pharmaceutical Waste & 1.17 & 0.011 \\
\hline Sharps & 0.95 & 0.009 \\
\hline General Waste & 9.77 & 0.091 \\
\hline Total Medical Waste Generated & 17.56 & 0.164 \\
\hline
\end{tabular}

Proportion of different types of health care waste in relation to the total HCW generated was identified as follows (Figure 1).

Total Weight of Medical Waste Generated In Different Wards: The largest portion of total waste were contributed by gynecological ward which accounted for $5.08 \mathrm{~kg} /$ day $(28.90 \%)$ while the lowest proportion was generated in office which accounted $0.22 \mathrm{~kg} /$ day (1.30\%) Figure 2. The presence of

Table 3: Comparison of total health care waste, general waste and hazardous waste between different wards, in MTU teaching hospital, Bench Maji zone, SWE, 2017.

\begin{tabular}{|c|c|c|c|}
\hline \multirow{2}{*}{ Name of wards } & \multicolumn{2}{|c|}{ Mean rank } \\
\cline { 2 - 4 } & Total HCW & General waste & Hazardous waste \\
\hline Gynecological Ward & 50.14 & 31.93 & 24.00 \\
\hline Medical Ward & 30.36 & 37.57 & 38.14 \\
\hline Surgical Ward & 31.36 & 34.07 & 35.57 \\
\hline Opd & 18.57 & 13.86 & 32.43 \\
\hline Laboratory & 16.14 & 9.86 & 29.43 \\
\hline Pediatric Ward & 29.57 & 35.71 & 7.50 \\
\hline Different Offices & 4.14 & 12.29 & 7.50 \\
\hline Kitchen & 47.71 & 52.71 & 44.324 \\
\hline Chi-Square & 44.604 & 41.815 & 0.000 \\
\hline Asymp. Sig. & 0.001 & 0.001 & \\
\hline
\end{tabular}

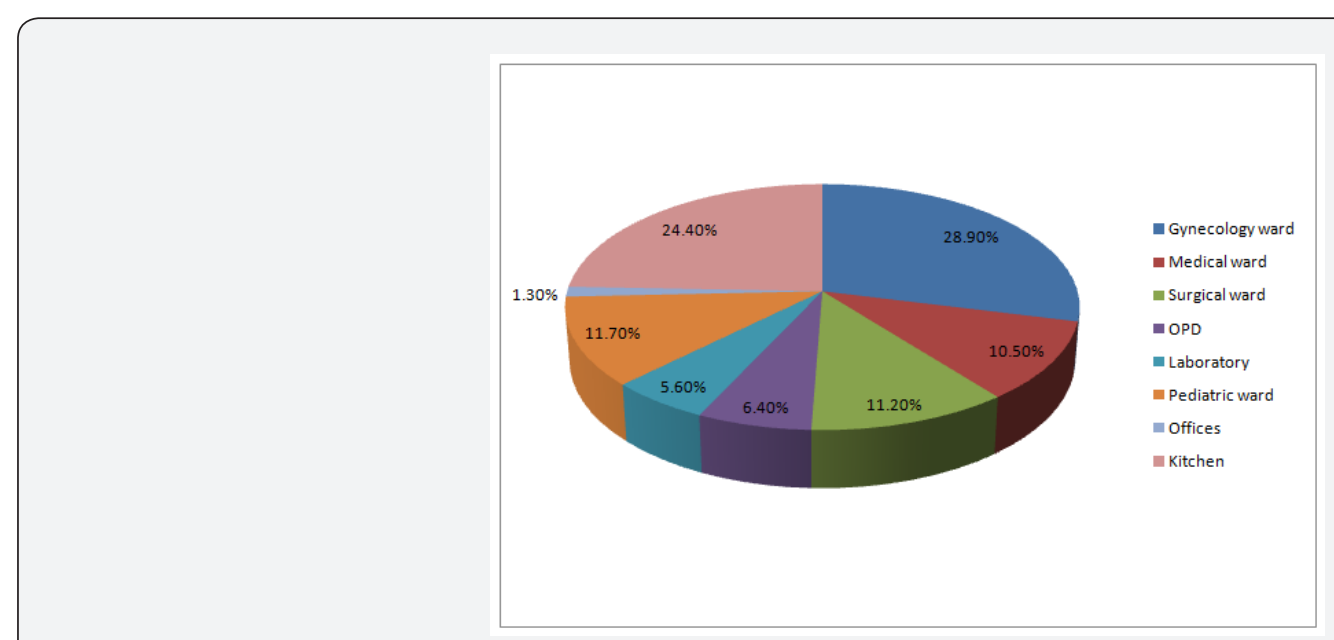

Figure 2: Percentage of total health care waste generation in each department in MTU teaching hospital, Bench Maji zone, SWE, 2017. 
The estimated annual waste generation rate: The annual healthcare waste generation rate can be estimated by using the mean healthcare waste generation rate in $\mathrm{kg}$ per day multiplied by 365 days (by assuming the mean of healthcare waste generation rate within seven consecutive days may represent the whole year). Thus, the estimated annual waste generation rate was $6409.4 \mathrm{Kg} /$ year or $59.86 \mathrm{~kg} /$ bed/year (pathological 12.045 $\mathrm{kg} / \mathrm{bed} /$ year, infectious $7.3 \mathrm{~kg} / \mathrm{bed} /$ year, pharmaceutical 4.015 $\mathrm{kg} / \mathrm{bed} /$ year, sharps $3.285 \mathrm{~kg} / \mathrm{bed} /$ year, and general waste $33.215 \mathrm{~kg} / \mathrm{bed} /$ year) (Table 4).

*Annual HCW generation rate $(\mathrm{kg} /$ year) $=$ Mean (average daily health care waste generated in all wards)*365

**Annual HCW generation rate $(\mathrm{kg} / \mathrm{bed} /$ year $)=$ Total HCW generation rate per year $(\mathrm{kg} / \mathrm{bed} /$ day $) * 365$

Table 4: Estimated quantity of HCW generated per year in MTU teaching hospital, Bench Maji zone, SWE, 2017.

\begin{tabular}{|c|c|c|c|c|}
\hline Type of Waste & $\begin{array}{c}\text { Mean (Average Daily } \\
\text { Health Care Waste } \\
\text { Generated in All Wards) }\end{array}$ & $\begin{array}{c}\text { Total HCW Generation } \\
\text { Rate Per Year (Kg/Bed/ } \\
\text { Day) }\end{array}$ & $\begin{array}{c}\text { *Total HCW Generation } \\
\text { Rate Per Year (Kg/Year) }\end{array}$ & $\begin{array}{c}\text { **Total HCW Generation } \\
\text { Rate Per Year (Kg/Bed/ } \\
\text { Year) }\end{array}$ \\
\hline Pathological Waste & 3.51 & 0.033 & 1281.15 & 12.045 \\
\hline Infectious Waste & 2.16 & 0.020 & 788.4 & 7.3 \\
\hline Pharmaceutical Waste & 1.17 & 0.011 & 427.05 & 3.015 \\
\hline Sharps & 0.95 & 0.009 & 346.75 & 33.215 \\
\hline $\begin{array}{c}\text { General Waste } \\
\text { Total Hazardous Waste } \\
\text { Generated }\end{array}$ & 9.77 & 0.091 & 2843.35 & 26.645 \\
\hline $\begin{array}{c}\text { Total Medical Waste } \\
\text { Generated }\end{array}$ & 7.79 & 0.073 & 6409.4 & 59.86 \\
\hline
\end{tabular}

\section{Evaluation of Health Care Waste Management System}

Segregation: Even if the contribution of waste segregation at source of generation to improve waste management practices were superb, in MTU teaching hospital it was not practiced appropriately. The distributions of plastic bags (waste collection container) in different department were not adequate and found at the right place to dispose on it. During our observation time mixed types of wastes such as hazardous and general wastes were found together in Black and Yellow boxes. Even though safety boxes were found in all wards the health professionals and other visitors fill it with various mixed waste including sharps. Generally, segregation of medical waste at point of generation was not properly practiced in studied departments.

Temporary Waste Storage, Reusing and Recycling Options: Temporary waste storage site mean a place where medical waste is kept before it is transported to its final disposal place or it is a place to segregate wastes to search the presence of any recyclable or reusable wastes. The result from this study revealed that there was no separate place for waste storage in the hospital rather they use plastic buckets to store health care wastes temporarily. Temporary waste storage containers were not sited in appropriate place which was not secured and accessible for all visitors to hospital. There were not any observed activities performed by health professionals or other staff to reuse or recycle materials.

Waste Collection, Transportation and Handling: During observation time it was identified that waste was not allowed to accumulate within the wards for more than a day. However, wastes which were found in temporary storage site wait for more days before it is taken to its final disposal site. The main problem observed in this hospital was hazardous and general wastes were not collected transported separately at onsite as well to offsite. Also wastes were not disposed to containers according to the appropriate seal and label. Medical waste storage and transporting plastic buckets were not treated with disinfectants like sodium hypo chlorate as required as possible. Only some 5 of 21 waste collectors/waste handlers had worn glove and boots during waste collection and transportation of healthcare wastes.

Waste Disposal: Different types of medical waste disposal mechanisms for different categories of wastes were used in MTU teaching hospital during this data collection time. The common types of medical waste disposal methods used were incinerator, open pit burning, placenta pit and open dumping. Placenta pit was mainly used for disposing placenta. Also they use it for disposal of certain types of pathological and infectious medical wastes. The placenta pit was constructed from slab and protected with appropriate cover. Incinerator was the other disposal method commonly used in this hospital. However, it was not operated by trained person and was used for burning of wastes which were not appropriate. The other issue was waste handlers prefer open burning rather than using other best options of medical waste disposal methods. It was observed that mixed disposal of different wastes in open and unprotected pit were practical in the hospital compound. The types of wastes disposed in open pit were used batteries, broken thermometers, plastics like IV-bags, garbage wastes and others.

Training and Budget Allocation: Based on the response from hospital manager training was given for health care workers only about waste management previously. But of total waste handlers most of the replied that they did not took a well organized 
training in the past one year or before. Also there was lack of planning for improved medical waste management practice and shortage of budget allocated for buying important facilities used in waste management.

Medical Waste Management Committee, Procedures and Guidelines: There was not functional medical waste management committee in this hospital during data collection time and operational standard or guidelines were not applied for medical waste management.

\section{Discussion}

Mizan Tepi university teaching hospital is one of the major hospitals visited by large number of patients in Bench Maji zone which serve more than 2 million people. During data collection time the hospital has a total of 107 beds. The major services addressed and expected to generate different types of medical wastes and included in this study were OPD, gynecology ward, medical ward, surgical ward, laboratory, pediatric ward, different offices and kitchen.

The quantity of Health care waste produced from different facility is varies depending up on numerous factors such as income of the country, established waste management methods, hospital specialization, proportion of reusable items employed in hospital, proportion of patients treated on a day-care basis and number of beds.

The result obtained from this study revealed that the daily generation rate of health care waste in MTU teaching hospital was $0.164 \mathrm{~kg} / \mathrm{bed} /$ day. This result was lower than a result obtained in France [11], Bangladesh [12], Egypt [13] and Debre Birhan, Ethiopia [9], with a value of $3.3 \mathrm{~kg} / \mathrm{bed} /$ day, $1.24 \mathrm{~kg} / \mathrm{bed} /$ day, $1.03 \mathrm{~kg} / \mathrm{bed} /$ day and $0.405 \mathrm{~kg} / \mathrm{bed} /$ day respectively. This variation may be attributed to a variety of factors that contribute to the variability of the reported HCWGR, such as different hospital services, uncertainty on whether the non-hazardous fraction is included in the quantification of HCWGR, the units of expressing HCWGR, financial factors and others [1,14].

According to a WHO report, around $85 \%$ of the hospital wastes are actually non hazardous or general wastes, and the remaining 10-25\% is hazardous in nature [4]. However, the result from this hospital identified that of total stream of health care wastes generated $0.091 \mathrm{~kg} / \mathrm{bed} /$ day (55.5\%) was general waste and the remaining $0.073 \mathrm{~kg} / \mathrm{bed} /$ day (44.5\%) was hazardous waste which was not coherent with a stated value by WHO. This result was comparable with a result obtained in Nigeria where $41 \%$ of the total health care waste generated was hazardous [15]. But it was much bigger than a result identified in Sudan where only $20 \%$ of the total health care waste stream generate are hazardous [8]. This was more of attributed to inappropriate segregation practice of health care wastes generated in the hospital [16].

Different types of wastes were generated in this studied hospital with varies magnitude. From total health care waste stream generated total hazardous wastes generated in MTU teaching hospital constitutes pathological waste $(0.033 \mathrm{~kg} / \mathrm{bed} /$ day) and infectious waste $(0.02 \mathrm{~kg} / \mathrm{bed} /$ day $)$, waste together constitutes $32.3 \%$, pharmaceutical waste $0.011 \mathrm{~kg} / \mathrm{bed} /$ day (6.7\%), and sharps $0.009 \mathrm{~kg} /$ bed (5.5\%). This result was bigger than a report from world Health organization (WHO), where the distribution of health care wastes from hospitals in developing countries are expected to be $15 \%$ pathological and infectious waste, $1 \%$ sharp waste, and $3 \%$ pharmaceutical wastes [7]. This high percentage in contrast to WHO guideline was expected to be due to the widespread use of disposables rather than reusable materials for different purposes [17].

In this study the largest portions of total waste were contributed by gynecological ward which accounted for 5.08 $\mathrm{kg} /$ day $(28.90 \%)$ while the lowest proportion was generated in office which accounted $0.22 \mathrm{~kg} /$ day $(1.30 \%)$. This study was similar to a study done in Tanzania which showed that the waste generation per hospital section includes pediatric 13\%, orthopedic $16 \%$, Gynecology $18 \%$, surgical $25 \%$, and medical $15 \%[18]$.

Kruskal Wallis test were used to test the presence of significant difference among different departments based on health care waste generated. The result revealed that there was statistically a significant difference to mean of health care waste generated $(\chi 2=44.604, p$ value $=0.001)$, general waste generated $(\chi 2=41.815, \mathrm{p}$-value $=0.001)$ and hazardous waste generated $(\chi 2=44.324$, $p$-value $=0.000)$ between different wards measured. This result was similar with study conducted in Debre Berhan hospital which revealed that there was statistically significance difference of health care waste $(X 2=43.459$, $p$-value $<0.001)$, general health care waste $(\mathrm{X} 2=48.914$, p-vale $<0.001)$ and hazardous health care waste among different sections [9].

This may be associated with a difference in extent and types of health care activities performed in various departments. Segregation is useful since it prevents the contamination of non-hazardous waste by the hazardous waste and making the whole waste stream hazardous. Thus, this method will reduce the toxicity and the volume of the waste stream. Moreover, segregation makes it easier to transport the waste. Waste is segregated depending on the quantity, composition, and the disposal method of the waste stream [19].

A result obtained in MTU teaching hospital revealed that health care wastes were not separated in to different categories appropriately. During our observation time mixed types of wastes such as hazardous and general wastes were found together in Black and Yellow boxes. Generally, segregation of medical waste at point of generation was not properly practiced in all studied departments. This result was similar with a finding obtained in Addis Ababa (Ethiopia) where almost all of assessed hospitals reported that there was no segregation of waste into infectious, pathological and pharmaceutical, and had no separate bins for the collection of infectious waste [20]. 
This may be associated with inadequate distribution of appropriate boxes, poor attention given by the generators of the waste such as doctors, nurses, paramedical staff, patients, and their attendants about the amount, quantity and type of waste they generate and the way it is disposed and insufficient enforcement to improve waste segregation practice by top management [4].

Temporary waste storage site mean a place where medical waste is kept before it is transported to its final disposal place or it is a place to segregate wastes to search the presence of any recyclable or reusable wastes [20].

The result from this study revealed that there was no separate place for waste storage in the hospital rather they store health care wastes temporarily which were not sited in appropriate place which was not secured and accessible for all visitors to hospital, which were contrary to WHO regulations [21]. This result was similar with a study conducted in Debre Berhan [9].

Medical waste may be disposed using different methods which many countries have adopted. However, the disposal of medical waste needs to be carried out in a way that neither the environment nor the health conditions of people are put at risk as they are hazardous [22].

The common types of medical waste disposal methods used were open pit burning and open dumping in addition to other types of waste disposal methods including placenta pit. This result was not good in contrast to a study done in Addis Ababa where incinerator was the main disposal method in hospitals [20]. And also it was not in coherent condition with a guideline stated by world health organization (WHO) for disposal of health care wastes.

\section{Conclusion}

The total generation rate of health care waste was coherent with expected amount to be generated from health care facilities in developing countries by world health organization. But the magnitude of hazardous waste was against the estimate set by world health organization (WHO).

It is known that waste segregation at source of generation is crucial to improve waste management practices as well to decrease its volume, but in Mizan Tepi University teaching hospital was not practiced appropriately in similar way to WHO guideline. There were observed problems related with the distributions of plastic bags (waste collection container) in different department with enough amount and appropriate place.

Waste was temporarily stored in different corridors randomly which was not secured and accessible for all visitors to hospital. Wastes were not transported separately from generation to disposal site. The types of health care waste disposal methods used commonly were against the guidelines of WHO which were open pit burning open dumping.
Functional health care waste management committee was not available. Similarly we did not seen any operational standard or guidelines applied in this hospital to manage health care waste.

\section{Recommendation}

a) All waste generators such as doctors, nurses, paramedical staff, patients, and their attendants should segregate wastes at source of generation using different types of waste collection containers according to their label.

b) The hospital management should apply enforcement for the proper application of the principle of waste segregation based on WHO guidelines and provide adequate waste collection containers for all departments.

c) Better options of health care waste disposal methods should be designed and applied by top management.

d) Continuous training with regard to HCWM should be given for waste generators and other concerned professionals.

e) Infection prevention and control committee should be established and strengthen to improve existing health care waste management problems.

\section{Strength and Limitation of the Study}

\section{Strength of the Study}

i. Since the study was the first in this zone, it can be a baseline data and input for different stakeholders for better planning and management of health care waste in the hospital and the country as a whole.

ii. Supervision was made with more experienced professionals during waste collection and measurement.

\section{Limitation of the Study}

A. Even if health care waste generation rate can be affected by seasonal variation, this research was done using cross sectional methods.

\section{Competing Interest}

The authors declare that there is no competing interest regarding the publication of this paper entitled assessment of health care waste generation rate and evaluation of its management system in Mizan Tepi university teaching hospital (MTUTH), Bench Maji Zone, South West Ethiopia.

\section{Acknowledgement}

Our heartfelt thanks go to Mizan Tepi University College of Health Science for the provision of full support for the accomplishment of this research. We would like to thank the Mizan Tepi University Teaching Hospital, Bench Maji Zone Health Department, and Mizan Aman Health Unit for their cooperation during the process of data collection. 


\section{References}

1. Julija Guscaa, Silvija Nora Kalnins, Dagnija Blumberga, Larissa Bozhko, Zauresh Khabdullina, et al. (2015) Assessment method of health care waste generation in Latvia and Kazakhstan. Energy Procedia 72: 175179

2. World Health Organization (WHO) (2011) Some Basic Information on Healthcare Wastes.

3. Glenn M, Ravi Agarwal (1999) Clinical waste in Developing Countries. An analysis with a Case Study of India, and a Critique of the Basle TWG Guidelines.

4. Mukesh Yadav (2001) Hospital Waste - A Major Problem. JKPractitioner 8(4): 276-282.

5. World health organization (WHO) (2000) Starting Health Care Waste Management In Medical Institutions. Healthcare Waste Information Series p. 1-16

6. Dasimah Omara, Siti Nurshahida Nazil, Subramaniam AK (2012) Clinical Waste Management in District Hospitals of Tumpat, Batu Pahat and Taiping. Procedia - Social and Behavioral Sciences 68: 134-145.

7. World Health Organization (2004) Healthcare waste management.

8. NO Ahmed, GA Gasmelseed (2014) Assessment of Medical Solid Waste Management in Khartoum State Hospitals. Journal of Applied and Industrial Sciences 2(4): 201-205.

9. Esubalew Tesfahun, Abera Kume (2007) Assessment of Health Care Waste Generation Rate and Evaluation of Health Care Waste Management in Debre Birhan Zonal Hospital, Amhara Region. Addis Ababa University, Ethopia.

10. Tadesse Alemayehu, Alemayehu Worku, Nega Assefa (2015) Community risk perception on healthcare wastes in hospitals and health centres of Eastern Ethiopia. Science Journal of Public Health. 3(1): 37-43.

11. Windfeld E, Brooks M (2015) Medical waste management-A review. Environ Manage 163: 98-108.
12. MM Hassan, Shafiul Azam Ahmed, K Anisur Rahman, Tarit Kanti Biswas (2008) Pattern of Medical Waste Management: Existing Scenario in Dhaka City, Bangladesh. BMC Public Health 8: 36.

13. Shouman E, Al Bazedi G, MH Sorour, AG Abulnou (2013) Management of hazardous medical waste treatment in Egypt. World Applied Sciences Journal 28: 804-808.

14. Komilis D (2016) Issues on medical waste management research Waste Manag 48: 1-2.

15. Ogbonna DN (2013) Characteristics and waste management practices of medical wastes in healthcare institutions in Port Harcourt, Nigeria. African Journal of Environmental and Waste Management 1(1): 13-21.

16. Mesfin W (2014) Assessment of Health Care Waste Segregation Practice and Associated Factors of Health Care Workers in Gondar University Health center, North West Ethiopia. Universal Journal of Public Health 4: 81-88.

17. Al Khatib IA (2014) Medical Waste Management Practices in a Palestinian District Hospitals, Palestine. In International Conference on Agriculture, Environment and Biological Sciences (ICFAE'14). Antalya, Turkey.

18. Kagonji IS (2003) Medical waste management in Muhimbili National Hospita, Tanzanial, East Africa.

19. Shareefdeen ZM (2012) Medical Waste Management and Control. Journal of Environmental Protection 3: 1625-1628.

20. Mesfin Kote Debere, Gelaye KA, Alamdo AG, Trifa ZM (2013) Assessment of the health care waste generation rates and its management system in hospitals of Addis Ababa, Ethiopia. BMC Public Health p. 13:28.

21. Pruss A (1999) Safe management of waste from health activities.

22. C Bokhoree et al. (2014) Assessment of Environmental and Health Risks Associated with the Management of Medical Waste in Mauritius. APCBEE Procedia 9: 36-41.

Your next submission with Juniper Publishers
will reach you the below assets
- Quality Editorial service
- Swift Peer Review
- Reprints availability
- E-prints Service
- Manuscript Podcast for convenient understanding
- Global attainment for your research
- Manuscript accessibility in different formats
( Pdf, E-pub, Full Text, Audio)
- Unceasing customer service
Track the below URL for one-step submission
https://juniperpublishers.com/online-submission.php

